\title{
UV-Enhanced NaClO Oxidation of Nitric Oxide from Simulated Flue Gas
}

\author{
Shao-long Yang, Zhi-tao Han, Jing-ming Dong, Zi-sheng Zheng, and Xin-xiang Pan \\ Marine Engineering College, Dalian Maritime University, Dalian 116026, China \\ Correspondence should be addressed to Xin-xiang Pan; panxx@dlmu.edu.cn
}

Received 11 November 2015; Revised 19 January 2016; Accepted 1 February 2016

Academic Editor: Claudio Di Iaconi

Copyright (C) 2016 Shao-long Yang et al. This is an open access article distributed under the Creative Commons Attribution License, which permits unrestricted use, distribution, and reproduction in any medium, provided the original work is properly cited.

A wet de- $\mathrm{NO}_{x}$ technique based on an UV-enhanced $\mathrm{NaClO}$ oxidation process was investigated for simulated flue gas of a diesel engine using a bench-scale reaction chamber. The effects of UV irradiation time, initial $\mathrm{pH}$ value, and available chlorine concentration of $\mathrm{NaClO}$ solution were studied, respectively. The results showed that when the UV irradiation time was 17.5 min and the initial $\mathrm{pH}$ value of $\mathrm{NaClO}$ solution was 6 , NO removal efficiency of $\mathrm{UV} / \mathrm{NaClO}$ solution was increased by $19.6 \%$ compared with that of $\mathrm{NaClO}$ solution. Meanwhile, when the available chlorine concentration of $\mathrm{NaClO}$ solution decreased from $0.1 \mathrm{wt} \%$ to $0.05 \mathrm{wt} \%$, the enhancement in $\mathrm{NO}$ removal efficiency of $\mathrm{UV} / \mathrm{NaClO}$ solution increased from $19.6 \%$ to $24 \%$, compared with that of $\mathrm{NaClO}$ solution. The reaction pathways of $\mathrm{NaClO}$ solution photolysis and $\mathrm{NO}$ removal by $\mathrm{UV} / \mathrm{NaClO}$ process were preliminarily discussed. The results suggested that $\mathrm{HOCl}$ might be the most active species that released many $\mathrm{UV}$-induced photooxidants through photolysis reactions, which played an important role in NO removal process.

\section{Introduction}

More and more attention has been paid to nitrogen oxides $\left(\mathrm{NO}_{x}\right)$ emissions in recent years. The risks posed by atmospheric $\mathrm{NO}_{x}$ can be enormous, resulting in catastrophic consequences [1] (e.g., acid deposition, formation of tropospheric ozone, photochemical smog, and aerosol warming) to human health and environment. Atmospheric $\mathrm{NO}_{x}$ originates from both anthropogenic and natural sources, and flue gas emission from burning fossil fuels by internal combustion engines is one of the most significant contributors to the anthropogenic sources [2]. Currently, the common practice in many industries is to implement more stringent regulations $[3,4]$ in order to control $\mathrm{NO}_{x}$ emissions from vehicle, power plants, and ocean-going ships.

To mitigate $\mathrm{NO}_{x}$ emissions from flue gas of internal combustion engines, a variety of technologies have been proposed to meet strict regulations on $\mathrm{NO}_{x}$ emission. Such methods are divided into two main categories $[1,5]$ : (i) dry techniques and (ii) wet techniques. Technologies within the first classification mainly include exhaust gas recirculation (EGR) [6], selective catalytic reduction (SCR) [7], nonthermal plasma (NTP) [8], electrochemical reduction [9], and lean $\mathrm{NO}_{x}$ traps [10]. For diesel engines, the commonly used commercial technologies are EGR and SCR at present. EGR can reduce the amount of $\mathrm{NO}_{x}$ generated during combustion by lowering the oxygen content in the cylinder and increasing the specific heat capacity of the air [6]. However, this technique is so complex that it is not suitable for retrofit. SCR can be installed with few engine modifications and it can remove more than $90 \%$ of $\mathrm{NO}_{x}$ from flue gas. But some problems with high working temperature $\left(300-400^{\circ} \mathrm{C}\right)$ and catalyst poisoning effect will restrict the extensive applications of this technique [11]. Consequently, alternative cost-efficient wet techniques, which are capable of significantly absorbing nitric oxide (NO) in scrubbing water, are becoming more attractive over the past decades. As $\mathrm{NO}$ is the major component of $\mathrm{NO}_{x}$ emissions and is of low solubility, it cannot be removed easily. Thus a number of recent studies take use of wet scrubbing agents [12] to oxidize $\mathrm{NO}$ to soluble $\mathrm{NO}_{2}$. The oxidants include $\mathrm{H}_{2} \mathrm{O}_{2}$ [13], $\mathrm{NaClO}_{2}$ [14], $\mathrm{NaClO}$ [15], $\mathrm{KMnO}_{4}$ [16], $\mathrm{Na}_{2} \mathrm{~S}_{2} \mathrm{O}_{8}$ [17], and $\mathrm{Fe}(\mathrm{II})$ EDTA [18]. Among these oxidants, $\mathrm{NaClO}[19,20]$ is found to be one of the most promising chemicals for NO oxidation because of its low cost [21] and self-regeneration 


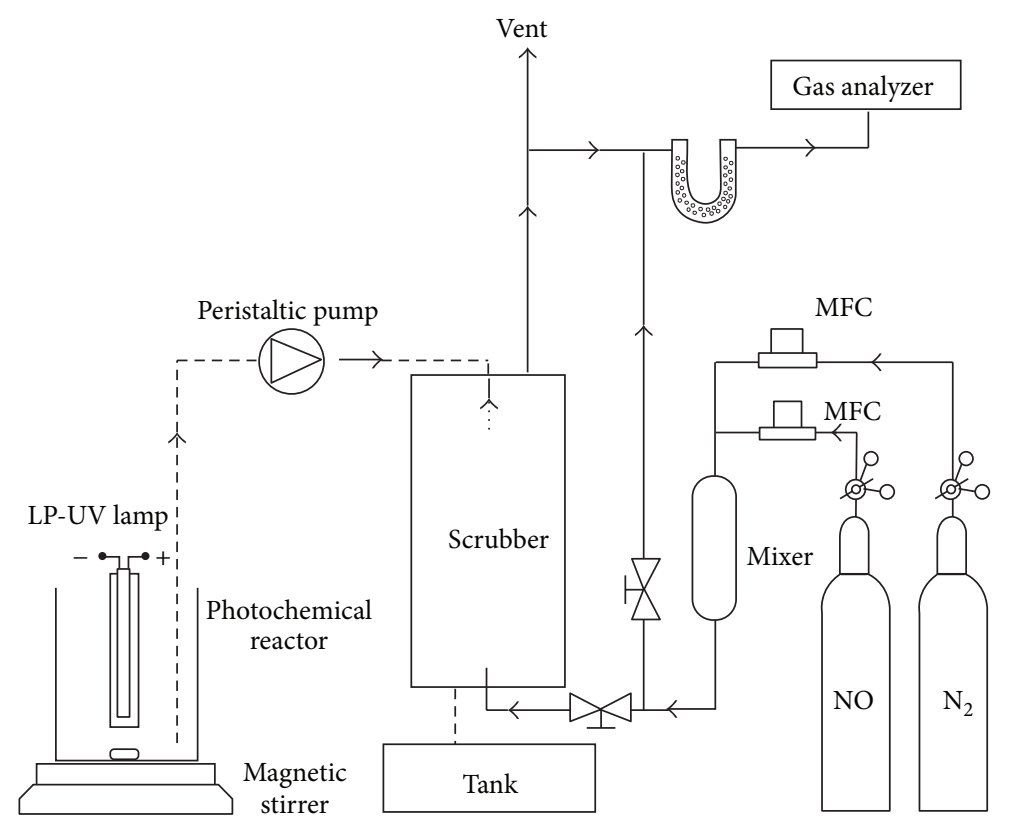

FIGURE 1: Schematic diagram of experimental system.

characteristic with an electrochemical cell. The results of previous studies indicated that this technique achieved a comparatively high NO removal efficiency, but one of the concerns was the high consumption of $\mathrm{NaClO}$ reagent $[15,22,23]$.

As a kind of inexpensive oxidant, $\mathrm{NaClO}$ was also used for wastewater treatment. In order to reduce the $\mathrm{NaClO}$ consumption, an advanced oxidation technique [24-26] by using a hybrid system of an UV lamp and $\mathrm{NaClO}$ solution was introduced in water treatment recently, and an enhancement effect had been achieved obviously. However, to the best of our knowledge, the effect of UV irradiation on the NO removal of $\mathrm{NaClO}$ solution has not been reported yet. In this work, the $\mathrm{NO}$ oxidation characteristic of $\mathrm{UV} / \mathrm{NaClO}$ aqueous solution in a bench-scale spraying column was studied to demonstrate the significance and advantages over conventional $\mathrm{NaClO}$ wet scrubbing techniques previously reported. The effects of UV irradiation time, initial $\mathrm{pH}$ value, and available chlorine concentration (ACC) of $\mathrm{NaClO}$ solution were investigated experimentally. The results showed that $\mathrm{UV} / \mathrm{NaClO}$ solution appeared to be a cost-effective method for removing NO from flue gas, and the possible reaction mechanism was discussed, although a number of questions regarding the chemistry of the process have been raised.

\section{Materials and Methods}

2.1. Experiment Apparatus. As shown in Figure 1, the experimental system consisted of a simulated flue gas system, a photochemical reactor, a bench-scale scrubber, and a flue gas analysis system.

The flue gas of a diesel engine was simulated by mixing different gas species: $\mathrm{NO}\left(9.8 \% \mathrm{NO}\right.$ with $90.2 \% \mathrm{~N}_{2}$ as balance gas) and $\mathrm{N}_{2}$ (99.9\%). The flow rate of material gas was regulated by a mass flow controller (D07-19B, Sevenstar Electronics, China), and the NO concentration of the simulated flue gas was adjusted by controlling the mixing ratio. All pipes, valves, regulators, and fittings were made up of stainless steel 316 grade or Teflon.

The photochemical reactor included a LP-UV lamp (UV-C, $253.7 \mathrm{~nm}, 11 \mathrm{~W}$, Philips, Holland), a column, and a magnetic stirrer. In order to reduce the interference of photochemical reaction by sunlight, the outside of the photochemical reactor was covered with aluminum foil.

The bench-scale scrubber (height: $30 \mathrm{~cm}$; internal diameter: $5.0 \mathrm{~cm}$ ) was a customized lucite spray column. The length of the reaction zone from the point at gas inlet to the spray nozzle (B1/4TT-SS+TG-SS0.4, Spraying System Co., America) was $20 \mathrm{~cm}$. The feed pump was a peristaltic pump (YZ1115, Longer Precision Pump, China).

The flue gas analysis system consisted of a U-shaped dryer and a gas analyzer (GA21-plus, Madur, Austria). The Madur GA21-plus gas analyzer was a portable electrochemical flue gas analyzer. It was equipped with two electrochemical sensors, which were used for measuring $\mathrm{NO}$ and $\mathrm{O}_{2}$ concentrations.

2.2. Experimental Procedures. $\mathrm{NaClO}$ solution was prepared using $\mathrm{NaClO}$ stock solution (ACC $5.0 \mathrm{wt} \%$, Aladdin, China) and deionized water (15.0 M $\Omega$, ELGA LabWater, England). The initial $\mathrm{pH}$ value of $\mathrm{NaClO}$ solution was adjusted to the desired value by adding freshly diluted $\mathrm{HCl}$ solution (AR, Sinoreagent, China). Then, $\mathrm{NaClO}$ solution was pretreated with UV irradiation in the photochemical reactor and the $\mathrm{pH}$ value of $\mathrm{NaClO}$ solution was online monitored with a pH meter (S210, Mettler-Toledo, Switzerland). Finally, the 
$\mathrm{UV} / \mathrm{NaClO}$ solution was delivered into the scrubber using the feed pump.

The initial NO concentration was kept at $300 \mathrm{ppm}$ and the gas flow rate was set to $1.5 \mathrm{~L} \cdot \mathrm{min}^{-1}$. Liquid absorption reactions occurred when the simulated flue gas entered into the bench-scale scrubber. The gas-liquid contact time between gas inlet and spraying nozzle was approximately $1.0 \mathrm{~s}$. Moreover, the NO concentration was measured by gas analyzer at an interval of $5 \mathrm{~s}$ during the absorption process. After being scrubbed, the simulated flue gas was discharged into atmosphere while the effluent of scrubbing liquid was collected in the bottom tank.

2.3. Data Processing. The scrubbing period for each set of experiments was kept for $5 \mathrm{~min}$. NO removal efficiency was obtained at steady-state conditions. NO removal efficiency was calculated by

$$
\eta_{\mathrm{NO}}(\%)=\frac{C_{\text {in }}-C_{\text {out }}}{C_{\text {in }}} \times 100 \%,
$$

where $C_{\text {in }}$ is the inlet NO concentration (ppm) and $C_{\text {out }}$ is the outlet NO concentration (ppm).

\section{Results and Discussions}

3.1. Comparison of Different Reaction Conditions. In order to demonstrate the UV enhancement effect of $\mathrm{UV} / \mathrm{NaClO}$ solution on NO removal through experiments, a set of comparative experiments were conducted (see Figure 2). As the major species in $\mathrm{NaClO}$ solution at $\mathrm{pH} 6$ were $\mathrm{Na}^{+}, \mathrm{Cl}^{-}$, $\mathrm{ClO}^{-}$, and $\mathrm{HClO}$, four different reaction conditions had been designed in our experiments. They were deionized water with UV irradiation (17.5 min), $\mathrm{NaCl}$ solution $(0.1 \mathrm{wt} \%)$ with UV irradiation (17.5 min), $\mathrm{NaClO}$ solution (ACC $0.1 \mathrm{wt} \%$ and $\mathrm{pH}$ 6) without UV irradiation, and $\mathrm{NaClO}$ solution (ACC $0.1 \mathrm{wt} \%$ and $\mathrm{pH}$ 6) with UV irradiation (17.5 min), respectively. From Figure 2, one can see that $\mathrm{NO}$ was removed slightly by $\mathrm{UV} / \mathrm{H}_{2} \mathrm{O}$ or $\mathrm{UV} / \mathrm{NaCl}$ solution, and the $\mathrm{NO}$ removal efficiencies of $\mathrm{NaClO}$ and $\mathrm{UV} / \mathrm{NaClO}$ were $31.3 \%$ and $50.9 \%$, respectively. The major ions in $\mathrm{NaCl}$ solution at $\mathrm{pH} 6$ were $\mathrm{Na}^{+}$and $\mathrm{Cl}^{-}$ions. The result of $\mathrm{UV} / \mathrm{NaCl}$ solution indicated that $\mathrm{Na}^{+}$ and $\mathrm{Cl}^{-}$ions in aqueous solution with UV irradiation made no contribution to NO removal. Consequently, the comparison results between $\mathrm{UV} / \mathrm{NaCl}$ and $\mathrm{UV} / \mathrm{NaClO}$ demonstrated that mainly $\mathrm{HClO}$ and $\mathrm{OCl}^{-}$in aqueous solution with $\mathrm{UV}$ irradiation played an important role in NO removal process. With the assistant of UV lamp, a remarkable improvement in $\mathrm{NO}$ removal efficiency using $\mathrm{UV} / \mathrm{NaClO}$ solution was observed, compared with that of $\mathrm{NaClO}$ solution without UV treatment. Under the same condition, $\mathrm{UV} / \mathrm{NaClO}$ scrubbing process has the potential to achieve the same NO removal efficiency with less consumption of $\mathrm{NaClO}$ reagent compared with that of $\mathrm{NaClO}$ wet scrubbing process. Therefore, $\mathrm{NaClO}$ solution with UV irradiation pretreatment appears to be an effective way to enhance NO removal efficiency and reduce the $\mathrm{NaClO}$ consumption.

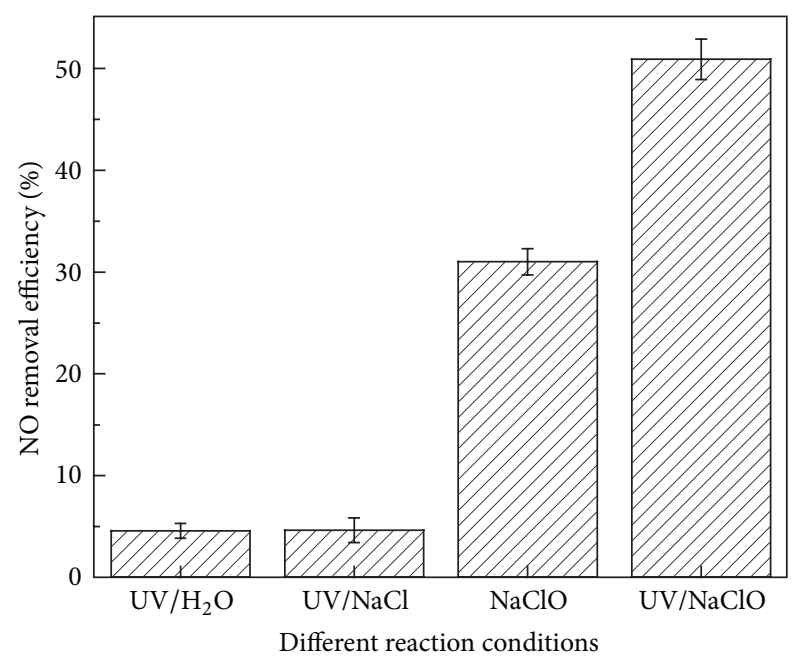

FIGURE 2: NO removal efficiency under different reaction conditions $\left(\mathrm{UV} / \mathrm{H}_{2} \mathrm{O}, 17.5 \mathrm{~min} ; \mathrm{UV} / \mathrm{NaCl}, 17.5 \mathrm{~min} / 0.1 \mathrm{wt} \%\right.$; $\mathrm{NaClO}$, ACC $0.1 \mathrm{wt} \%$ and $\mathrm{pH}$ 6; UV/NaClO, $17.5 \mathrm{~min} / \mathrm{ACC} 0.1 \mathrm{wt} \%$ and $\mathrm{pH} 6$ ).

According to the comparison results of four different reaction conditions, the UV-enhanced mechanism may be explained by the following reactions [24, 27-29]:

$$
\begin{aligned}
\mathrm{HOCl}+h \nu & \longrightarrow \mathrm{HO}^{\bullet}+\mathrm{Cl}^{\bullet} \\
\mathrm{OCl}^{-}+h \nu & \longrightarrow \mathrm{O}^{--}+\mathrm{Cl}^{\bullet} \\
\mathrm{OCl}^{-}+h \nu & \longrightarrow \mathrm{Cl}^{-}+\mathrm{O}\left({ }^{3} \mathrm{P}\right) \\
\mathrm{O}^{--}+\mathrm{H}_{2} \mathrm{O} & \longrightarrow \mathrm{HO}^{\bullet}+\mathrm{OH}^{-} \\
\mathrm{HO}^{\bullet}+\mathrm{HOCl} & \longrightarrow \mathrm{ClO}^{\bullet}+\mathrm{H}_{2} \mathrm{O} \\
\mathrm{HO}^{\bullet}+\mathrm{OCl}^{-} & \longrightarrow \mathrm{ClO}^{\bullet}+\mathrm{OH}^{-} \\
\mathrm{O}^{--}+\mathrm{O}_{2} & \longrightarrow \mathrm{O}_{3}^{-} \\
2 \mathrm{ClO}^{-} & \longleftrightarrow \mathrm{Cl}_{2} \mathrm{O}_{2} \\
2 \mathrm{Cl}_{2} \mathrm{O}_{2}+\mathrm{H}_{2} \mathrm{O} & \longrightarrow \mathrm{ClO}_{3}{ }^{-}+\mathrm{Cl}_{2} \mathrm{O}+\mathrm{OCl}^{-}+2 \mathrm{H}^{+} \\
\mathrm{Cl}_{2} \mathrm{O}_{2} & \longrightarrow \mathrm{Cl}_{2}+\mathrm{O}_{2} \\
\mathrm{ClO}^{\bullet}+\mathrm{NO} & \longrightarrow \mathrm{ClNO}_{2} \\
\mathrm{ClNO}_{2} & \longrightarrow \mathrm{Cl}^{\bullet}+\mathrm{NO}_{2}
\end{aligned}
$$

It was noteworthy that many UV-induced photooxidants (e.g., $\left.\mathrm{HO}^{*}, \mathrm{O}_{3}{ }^{-}, \mathrm{O}^{3} \mathrm{P}\right)$, and $\mathrm{ClO}^{*}$ ) were generated in situ through photolysis of $\mathrm{NaClO}$ solution. As these UV-induced photooxidants have an extremely strong oxidation ability, a significant part of $\mathrm{NO}$ was oxidized and absorbed into the $\mathrm{UV} / \mathrm{NaClO}$ solution. Without $\mathrm{UV}$ irradiation, $\mathrm{HOCl} / \mathrm{OCl}^{-}$ 


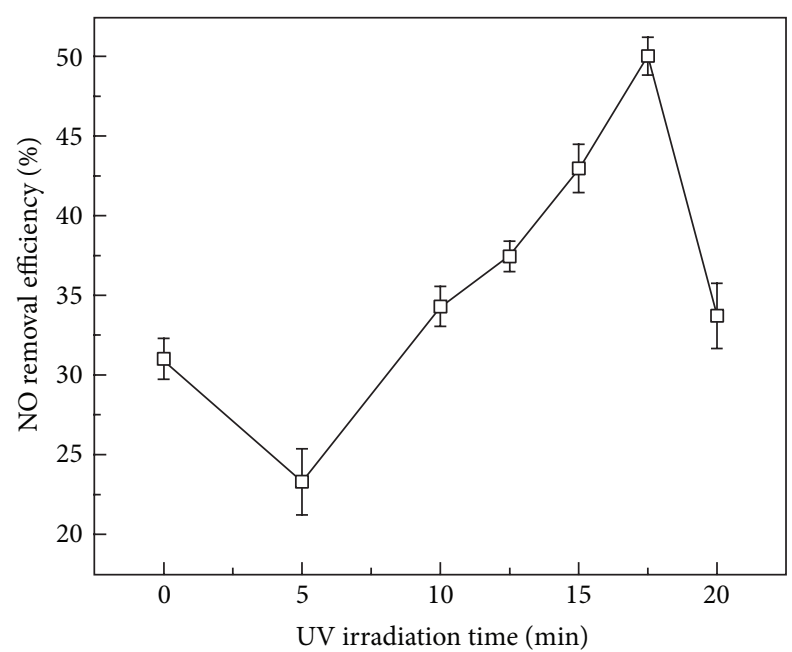

FIGURE 3: Effect of UV irradiation time on NO removal efficiency of $\mathrm{UV} / \mathrm{NaClO}$ solution (ACC $0.1 \mathrm{wt} \%$ and $\mathrm{pH} 6$ ).

was the active species reacting with NO in liquid phase, and the main reactions were given as follows $[15,30]$ :

$$
\begin{gathered}
\mathrm{NO}+\mathrm{HOCl} \longleftrightarrow \mathrm{NO}_{2}+\mathrm{HCl} \\
\mathrm{NO}+\mathrm{OCl}^{-} \longrightarrow \mathrm{NO}_{2}+\mathrm{Cl}^{-} \\
3 \mathrm{NO}_{2}+\mathrm{H}_{2} \mathrm{O} \longrightarrow 2 \mathrm{HNO}_{3}+\mathrm{NO}
\end{gathered}
$$

3.2. Effect of UV Irradiation Time. Figure 3 describes the influence of UV irradiation time on NO removal efficiency. One can see that although NO removal efficiency decreased in the first $5 \mathrm{~min}$, there was a remarkable increase in NO removal efficiency when UV irradiation time increased from $5 \mathrm{~min}$ to $17.5 \mathrm{~min}$. After that, when we further increased UV irradiation time from $17.5 \mathrm{~min}$ to $20 \mathrm{~min}$, the $\mathrm{NO}$ removal efficiency decreased sharply. Moreover, more and more $\mathrm{O}_{2}$ gas was released from scrubbing liquid with the increase of UV irradiation time (see Figure 4).

With the increase of UV irradiation time, photooxidants concentrations increased gradually via photochemical reactions ((2)-(11)) in UV/NaClO solution. Thus, NO removal efficiency of UV/NaClO solution was enhanced when the UV irradiation time increased from $5 \mathrm{~min}$ to $17.5 \mathrm{~min}$. However, several side reactions ((10)-(11)) occurred with further increase of UV irradiation time, resulting in a loss of photooxidants. These side reactions were also confirmed by the phenomenon that more $\mathrm{O}_{2}$ gas and bubbles were observed to escape from solution. Therefore, excessive UV irradiation resulted in a negative effect on NO removal efficiency of $\mathrm{UV} / \mathrm{NaClO}$ solution.

3.3. Effect of Initial pH Value of NaClO Solution. The effect of initial $\mathrm{pH}$ value on $\mathrm{NO}$ removal efficiencies of $\mathrm{NaClO}$ solution with or without UV irradiation is investigated experimentally and the results are shown in Figure 5. Without UV irradiation, the NO removal efficiency decreased with the initial $\mathrm{pH}$ value varying from 2 to 10 , which was similar to the

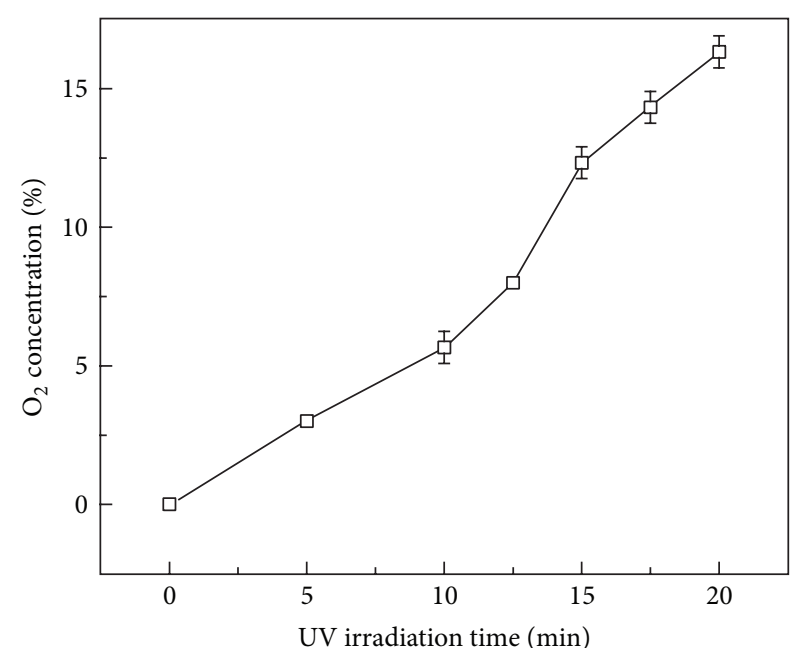

FIgURE 4: Effect of UV irradiation time on $\mathrm{O}_{2}$ production (UV/ $\mathrm{NaClO}, \mathrm{ACC} 0.1 \mathrm{wt} \%$, and $\mathrm{pH} 6$ ).

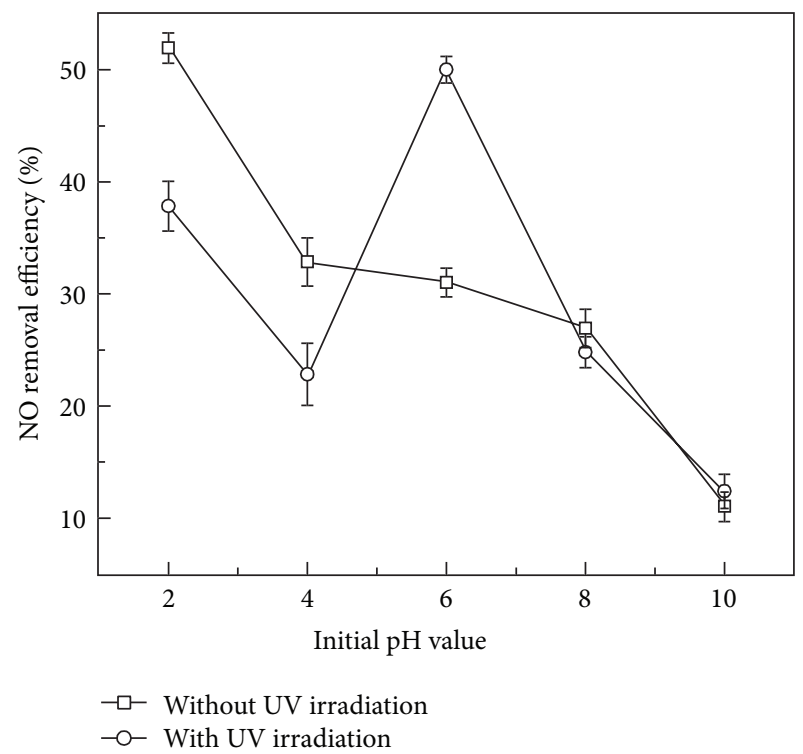

FIGURE 5: Effect of initial $\mathrm{pH}$ value on $\mathrm{NO}$ removal efficiency of $\mathrm{NaClO}$ solution (UV, $17.5 \mathrm{~min}$; $\mathrm{NaClO}$, ACC $0.1 \mathrm{wt} \%$ ).

experimental results of Mondal and Chelluboyana [20]. This phenomenon can be attributable to the following equations:

$$
\begin{aligned}
& \text { Free chlorine }= {\left[\mathrm{Cl}_{2}\right]+[\mathrm{HOCl}]+\left[\mathrm{OCl}^{-}\right] } \\
&+\left[\mathrm{Cl}_{3}{ }^{-}\right] \\
& \mathrm{HOCl}+\mathrm{H}^{+}+\mathrm{Cl}^{-} \longleftrightarrow \mathrm{Cl}_{2}+\mathrm{H}_{2} \mathrm{O} \\
& \qquad \mathrm{p} k_{a}=3.33\left(25^{\circ} \mathrm{C}\right) \\
& \mathrm{OCl}^{-}+\mathrm{H}^{+} \longleftrightarrow \mathrm{HOCl} \quad \mathrm{p} k_{a}=7.53\left(25^{\circ} \mathrm{C}\right) \\
& \mathrm{Cl}_{2}+\mathrm{Cl}^{-} \longleftrightarrow \mathrm{Cl}_{3}{ }^{-}
\end{aligned}
$$

When the initial $\mathrm{pH}$ value dropped below $4, \mathrm{Cl}_{2}$ was released from $\mathrm{NaClO}$ solution. Thus, direct gas phase reaction 
of $\mathrm{Cl}_{2}$ and $\mathrm{NO}$ [31] occurred in scrubbing chamber, which greatly enhanced the mass transfer efficiency and improved the NO removal efficiency. When the initial $\mathrm{pH}$ value increased from 4 to 10 , NO conversion decreased slowly at first and then dropped sharply. The liquid oxidation reactions were shown in (14)-(16). As $\mathrm{HOCl}$ was a stronger oxidizing agent than $\mathrm{OCl}^{-}[15,30]$, NO removal efficiency would decrease with the increase of the initial $\mathrm{pH}$ value, owing to the reduction of $\mathrm{HOCl}$ chlorine species in the solution.

As shown in Figure 5, with UV irradiation, UV/NaClO solution at $\mathrm{pH} 6$ exhibited the characteristic of an excellent scrubbing medium. When the initial $\mathrm{pH}$ value increased from 2 to 4 , the NO removal efficiency decreased because of outgassing of $\mathrm{Cl}_{2}$ during $\mathrm{UV}$ irradiation and reduction of direct gas phase oxidation. When the initial $\mathrm{pH}$ value varied from 4 to 6 , a significant increase of NO removal efficiency was measured. However, when the initial $\mathrm{pH}$ value increased from 6 to 10, the NO removal efficiency decreased gradually. According to the equilibrium concentrations of chlorine species with the change of $\mathrm{pH}$ in $\mathrm{NaClO}$ solution, when the initial $\mathrm{pH}$ value increased from 4 to 10 , the main chlorine species in $\mathrm{NaClO}$ solution were $\mathrm{HOCl} / \mathrm{OCl}^{-}$, which generated photolysis reactions ((2)-(11)). Although the molar absorption coefficient of $\mathrm{OCl}^{-}$was higher than $\mathrm{HOCl}$, the side reaction rate of $\mathrm{HO}^{-}$and $\mathrm{OCl}^{-}$made $\mathrm{OCl}^{-}$to be a more strong free radical scavenger than $\mathrm{HOCl}$. The difference of $\mathrm{NO}$ removal efficiencies with the change of initial $\mathrm{pH}$ value indicated that $\mathrm{HOCl}$ was the most active species that released the largest amount of photooxidants through photolysis reactions under the same UV irradiation condition. In addition, from Figure 6, one can see that $\mathrm{UV} / \mathrm{NaClO}$ solution at initial $\mathrm{pH} 6$ showed an apparent drop of $\mathrm{pH}$ value with the increase of $\mathrm{UV}$ irradiation time. $\mathrm{As}^{\mathrm{ClO}_{3}}{ }^{-}$was one of the photooxidants, its oxidation ability increased with the decrease of $\mathrm{pH}$ value. As a consequence, $\mathrm{ClO}_{3}{ }^{-}$also enhanced $\mathrm{NO}$ removal efficiency when the initial $\mathrm{pH}$ value dropped from 10 to 6 .

Moreover, as a kind of advanced oxidation technique, $\mathrm{UV} / \mathrm{NaClO}$ was also applied to treat wastewater. According to some recent studies $[25,32]$, photooxidants concentrations of $\mathrm{UV} / \mathrm{NaClO}$ solution were also changed as a function of the initial $\mathrm{pH}$ value. With this, UV irradiation was proved to make a remarkable improvement to the oxidability of $\mathrm{NaClO}$ solution at initial $\mathrm{pH} 6$.

3.4. Effect of ACC of NaClO Solution. Figure 7 shows the effect of ACC on $\mathrm{NO}$ removal efficiencies of $\mathrm{NaClO}$ solution with or without UV irradiation, respectively. Without UV irradiation, as the ACC of $\mathrm{NaClO}$ solution increased from 0 to $0.2 \mathrm{wt} \%$, NO removal efficiency varied from $3.6 \%$ to $41.7 \%$, which was due to the increase of $\mathrm{HClO}$ concentration $[20,33]$. With UV irradiation, one can see that NO removal efficiency of $\mathrm{UV} / \mathrm{NaClO}$ solution was greatly enhanced when the ACC of $\mathrm{NaClO}$ solution was less than or equal to $0.1 \mathrm{wt} \%$. However, when the ACC of $\mathrm{NaClO}$ solution was higher than $0.1 \mathrm{wt} \%$, UV irradiation had a negative effect on NO removal efficiency compared with that of non-UV irradiation. In addition, Figure 8 shows the effect of UV irradiation time on the $\mathrm{pH}$ value of $\mathrm{UV} / \mathrm{NaClO}$ solution under different ACC. It can be seen that the $\mathrm{pH}$ value dropped as the UV irradiation time

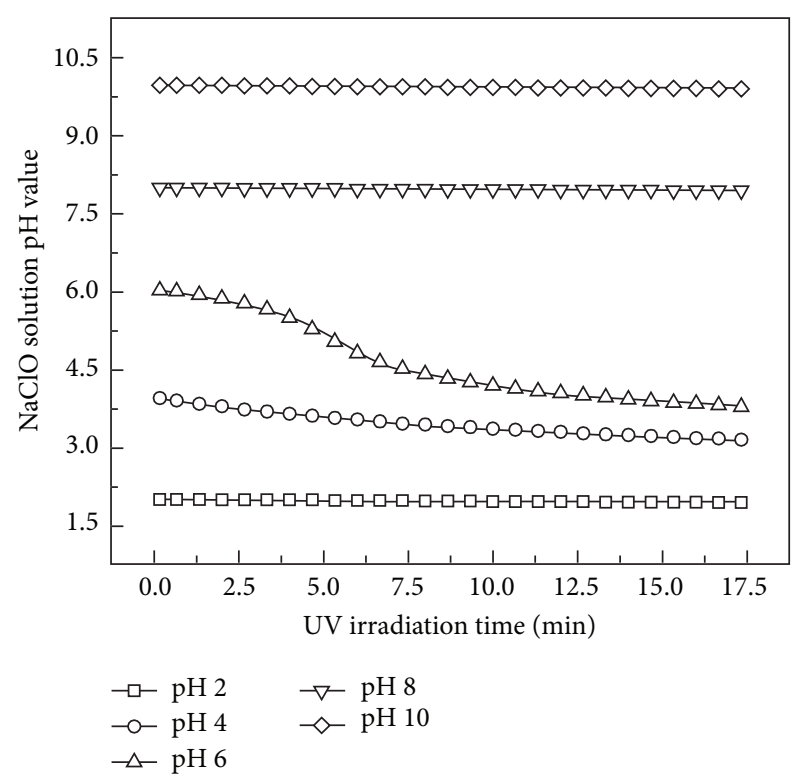

FIGURE 6: Effect of UV irradiation time on $\mathrm{UV} / \mathrm{NaClO}$ solution $\mathrm{pH}$ value with different initial $\mathrm{pH}$ value.

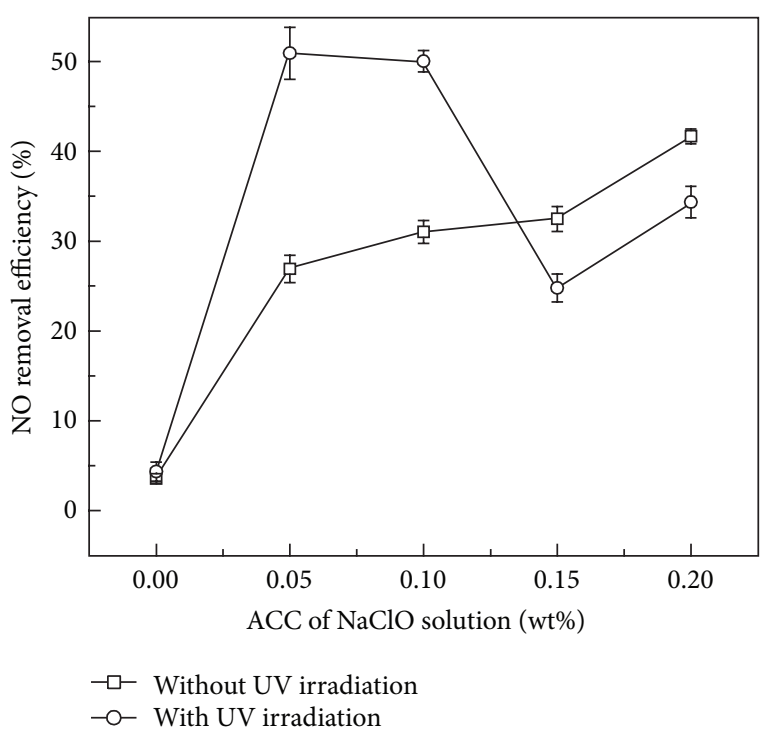

Figure 7: Effect of ACC on $\mathrm{NO}$ removal efficiency of $\mathrm{NaClO}$ solution (UV, $17.5 \mathrm{~min} ; \mathrm{NaClO}, \mathrm{pH}$ 6).

increased for $\mathrm{NaClO}$ solution with a specific ACC, and under the same UV irradiation time, the $\mathrm{pH}$ value of $\mathrm{UV} / \mathrm{NaClO}$ solution increased with the increase of ACC of $\mathrm{UV} / \mathrm{NaClO}$ solution.

When the ACC of $\mathrm{NaClO}$ solution was less than or equal to $0.1 \mathrm{wt} \%$, photooxidants concentrations increased via photolysis of $\mathrm{HOCl} / \mathrm{OCl}^{-}$. However, under the same UV irradiation condition, side reactions between photooxidants and $\mathrm{HOCl} / \mathrm{OCl}^{-}$increased as the $\mathrm{ACC}$ of $\mathrm{NaClO}$ solution varied from $0.1 \mathrm{wt} \%$ to $0.2 \mathrm{wt} \%$, which might explain that the $\mathrm{NO}$ removal efficiency was lower than that of $\mathrm{NaClO}$ solution without UV irradiation. In addition, as $\mathrm{ClO}_{3}{ }^{-}$was one of 
TABLE 1: NaClO de- $\mathrm{NO}_{x}$ technologies related investigations.

\begin{tabular}{|c|c|c|c|c|c|c|c|c|}
\hline $\begin{array}{l}\text { Reactor } \\
\text { type }\end{array}$ & $\begin{array}{l}\text { Gas-liquid } \\
\text { contact time } \\
\text { (s) }\end{array}$ & $\begin{array}{c}\mathrm{NaClO} \\
\text { concentration } \\
\left(\mathrm{mmol} \cdot \mathrm{L}^{-1}\right)\end{array}$ & $\begin{array}{l}\text { Initial pH } \\
\text { value }\end{array}$ & $\begin{array}{c}\text { Temperature } \\
\left({ }^{\circ} \mathrm{C}\right)\end{array}$ & $\begin{array}{l}\text { Initial NO } \\
\text { concentration } \\
\quad(\mathrm{ppm})\end{array}$ & $\begin{array}{l}\text { NO removal } \\
\text { efficiency (\%) }\end{array}$ & $\begin{array}{c}\text { NO removal per } \\
\mathrm{NaClO} \text { concentration } \\
\left(\mathrm{ppm} \mathrm{NO} /\left(\mathrm{mmol} \cdot \mathrm{L}^{-1}\right)\right. \\
\mathrm{NaClO})\end{array}$ & Reference \\
\hline $\begin{array}{l}\text { Packed } \\
\text { tower }\end{array}$ & $\sim 1.7$ & 169 & 5.3 & $\begin{array}{c}\text { Room } \\
\text { temperature }\end{array}$ & 100 & 80 & 0.58 & [15] \\
\hline $\begin{array}{l}\text { Bubbling } \\
\text { reactor }\end{array}$ & - & 176 & 3.18 & 20 & 1000 & 93.5 & 5.31 & {$[22]$} \\
\hline $\begin{array}{l}\text { Bubbling } \\
\text { reactor }\end{array}$ & - & 87 & 5.5 & 25 & 500 & 66.21 & 3.81 & {$[23]$} \\
\hline $\begin{array}{l}\text { Scrubbing } \\
\text { tower }\end{array}$ & $\sim 1$ & $\begin{array}{l}7 \text { (with UV } \\
\text { irradiation) }\end{array}$ & 6 & $\begin{array}{c}\text { Room } \\
\text { temperature }\end{array}$ & 300 & 50.60 & 21.69 & This work \\
\hline
\end{tabular}

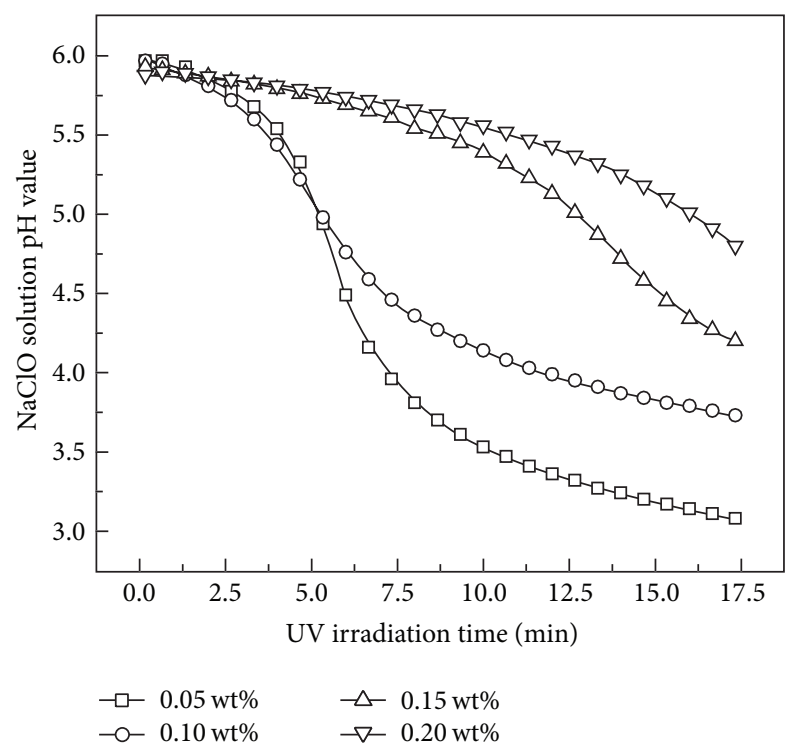

FIGURE 8: Effect of UV irradiation time on the $\mathrm{pH}$ value of UV/ $\mathrm{NaClO}$ solution with different ACCs.

the photooxidants, the oxidability of $\mathrm{UV} / \mathrm{NaClO}$ solution increased with the drop of $\mathrm{pH}$ value in acid condition, which might also contribute to an improvement in NO removal efficiency.

3.5. Comparison with Other Wet de-NO Technologies. Table 1 describes the comparison with other $\mathrm{NaClO}$ de- $\mathrm{NO}_{x}$ technologies in literature regarding NO removal. As the absorption conditions used by various researchers were different, the comparison of the $\mathrm{NO}$ removal efficiencies by various $\mathrm{NaClO}$ de- $\mathrm{NO}_{x}$ technologies was difficult. In order to demonstrate the enhancement effect of $\mathrm{UV} / \mathrm{NaClO}$ process, an evaluation criteria " $\mathrm{NO}$ removal per $\mathrm{NaClO}$ concentration (ppm $\left.\mathrm{NO} /\left(\mathrm{mmol} \cdot \mathrm{L}^{-1}\right) \mathrm{NaClO}\right)$ " was proposed and calculated by

$$
\mu_{\mathrm{NO}}=\frac{C_{\mathrm{in}} \times \eta_{\mathrm{NO}}}{C_{\mathrm{NaClO}}} \mathrm{ppm} /\left(\mathrm{mmol} \cdot \mathrm{L}^{-1}\right),
$$

where $C_{\text {in }}$ is the inlet NO concentration (ppm), $\eta_{\mathrm{NO}}$ is the NO removal efficiency (\%), and $C_{\mathrm{NaClO}}$ is the $\mathrm{NaClO}$ concentration $\left(\mathrm{mmol} \cdot \mathrm{L}^{-1}\right)$. Based on this criteria, the result of present work had a significant improvement as compared to previous $\mathrm{NaClO}$ solution wet scrubbing techniques [15, 22, 23].

From the equilibrium concentrations of chlorine species with the change of $\mathrm{pH}$ in $\mathrm{NaClO}$ solution, one can see that $\mathrm{HClO}$ was the main oxidizing agent in the result of Chen et al. [15] and Xiao et al. [23], while $\mathrm{Cl}_{2}$ was the main oxidizing agent in the result of Yang et al. [22]. As the oxidation potential of UV-induced photooxidants is much stronger than that of $\mathrm{HClO}$ and $\mathrm{Cl}_{2}$, the $\mathrm{NO}$ removal per $\mathrm{NaClO}$ concentration of this work is higher than that of Chen et al. [15], Yang et al. [22], and Xiao et al. [23]. Therefore, the combined techniques of $\mathrm{UV}$ and $\mathrm{NaClO}$ solution have the potential to reduce the $\mathrm{NaClO}$ consumption in the future.

\section{Conclusions}

The UV/NaClO wet scrubbing technique appeared to be a cost-effective method for $\mathrm{NO}$ control from simulated flue gas of a diesel engine. This novel de- $\mathrm{NO}_{x}$ method was investigated at the laboratory scale by considering several factors: $\mathrm{UV}$ irradiation time, initial $\mathrm{pH}$ value, and $\mathrm{ACC}$ of $\mathrm{NaClO}$ solution. The results showed that an enhancement of NO removal efficiency of $\mathrm{UV} / \mathrm{NaClO}$ solution was $19.6 \%$ under the following conditions: UV irradiation $17.5 \mathrm{~min}$, initial $\mathrm{pH}$ 6 , and ACC $0.1 \mathrm{wt} \%$. Compared with that of $\mathrm{NaClO}$ solution, the improvement in $\mathrm{NO}$ removal efficiency of $\mathrm{UV} / \mathrm{NaClO}$ solution might be attributable to a large amount of photooxidants produced by photolysis of $\mathrm{HClO} / \mathrm{OCl}^{-}$, which significantly improved the oxidation potential of $\mathrm{UV} / \mathrm{NaClO}$ solution and enhanced the NO removal efficiency. However, with the increase of both UV irradiation time ( $>17.5 \mathrm{~min})$ and the ACC $(>0.1 \mathrm{wt} \%)$ of $\mathrm{NaClO}$ solution, side reactions of photooxidants and $\mathrm{HOCl} / \mathrm{OCl}^{-}$resulted in a negative effect on $\mathrm{NO}$ removal efficiency. The initial $\mathrm{pH}$ value played a critical role in the $\mathrm{HOCl}$ concentration, which is suggested to be the most important species for $\mathrm{NO}$ removal in the $\mathrm{NaClO}$ wet scrubbing process with or without UV irradiation, respectively. Although UV irradiation has been shown to enhance the $\mathrm{NaClO}$ oxidation of $\mathrm{NO}$, more work needs to be done to quantify the results and reveal the reaction mechanisms of the $\mathrm{UV} / \mathrm{NaClO}$ wet scrubbing technology.

With the assistance of UV lamp, UV/NaClO process has the potential to cut down $\mathrm{NaClO}$ consumption as well 
as reduce storage space for chemical reagents by in situ generation of $\mathrm{NaClO}$ solution using electrochemical cell. With these advantages, $\mathrm{UV} / \mathrm{NaClO}$ process may be applicable to the treatment of flue gas from large power plants (e.g., coalfired thermal power plants, marine diesel engines), which are sensitive to the reagent consumption and footprint of de- $\mathrm{NO}_{x}$ systems.

\section{Conflict of Interests}

The authors declare that there is no conflict of interests regarding the publication of this paper.

\section{Acknowledgments}

This work was supported by the Science and Technology Plan Project of China's Ministry of Transport (Grant no. 2015328225150), the National Natural Science Foundation of China (Grant nos. 51402033 and 51479020), Scientific Research Fund of Liaoning Provincial Education Department of China (Grant no. L2014198), and the Fundamental Research Funds for the Central Universities (Grant no. 3132015209).

\section{References}

[1] K. Skalska, J. S. Miller, and S. Ledakowicz, "Trends in $\mathrm{NO}_{\mathrm{x}}$ abatement: a review," Science of the Total Environment, vol. 408, no. 19, pp. 3976-3989, 2010.

[2] N. Shi, B. Tu, W. Sun et al., "Room temperature efficient reduction of $\mathrm{NO}_{x}$ by $\mathrm{H}_{2}$ in a permeable compounded membranecatalytic reactor," Chemical Engineering Journal, vol. 283, pp. 929-935, 2016.

[3] J. Herdzik, "Emissions from marine engines versus IMO certification and requirements of tier 3," Journal of KONES Powertrain and Transport, vol. 18, no. 2, pp. 161-167, 2011.

[4] H. Jahn, "The international emission legislation for cars, trucks, motorcycles and non-road applications," in Internationaler Motorenkongress 2014, J. Liebl, Ed., pp. 273-283, Springer, 2014.

[5] D. J. Blatcher and I. Eames, "Compliance of Royal Naval ships with nitrogen oxide emissions legislation," Marine Pollution Bulletin, vol. 74, no. 1, pp. 10-18, 2013.

[6] MAN Diesel \& Turbo, "Emission project guide MAN B\&W two-stroke marine engines," Tech. Rep., 2013.

[7] S. Roy, M. S. Hegde, and G. Madras, "Catalysis for $\mathrm{NO}_{x}$ abatement," Applied Energy, vol. 86, no. 11, pp. 2283-2297, 2009.

[8] R. McAdams, "Prospects for non-thermal atmospheric plasmas for pollution abatement," Journal of Physics D: Applied Physics, vol. 34, no. 18, pp. 2810-2821, 2001.

[9] S. Bredikhin, K. Hamamoto, Y. Fujishiro, and M. Awano, "Electrochemical reactors for NO decomposition. Basic aspects and a future," Ionics, vol. 15, no. 3, pp. 285-299, 2009.

[10] B. West, S. Huff, J. Parks et al., "Assessing reductant chemistry during in-cylinder regeneration of diesel lean $\mathrm{NO}_{x}$ traps," $S A E$ Transactions, vol. 113, no. 4, pp. 1975-1985, 2004.

[11] D. W. Kwon, K. H. Park, and S. C. Hong, "Enhancement of SCR activity and $\mathrm{SO}_{2}$ resistance on $\mathrm{VO}_{x} / \mathrm{TiO}_{2}$ catalyst by addition of molybdenum," Chemical Engineering Journal, vol. 284, pp. 315324, 2016.
[12] R.-T. Guo, J.-K. Hao, W.-G. Pan, and Y.-L. Yu, "Liquid phase oxidation and absorption of NO from flue gas: a review," Separation Science and Technology, vol. 50, no. 2, pp. 310-321, 2015.

[13] J. Ding, Q. Zhong, S. Zhang, F. Song, and Y. Bu, "Simultaneous removal of NOX and $\mathrm{SO}_{2}$ from coal-fired flue gas by catalytic oxidation-removal process with $\mathrm{H}_{2} \mathrm{O}_{2}$," Chemical Engineering Journal, vol. 243, pp. 176-182, 2014.

[14] Y. Zhao, F. Liu, T. Guo, and Y. Zhao, "Experiments and reaction characteristics of liquid phase simultaneous removal of $\mathrm{SO}_{2}$ and NO," Science in China, Series E: Technological Sciences, vol. 52, no. 6, pp. 1768-1775, 2009.

[15] L. Chen, C.-H. Hsu, and C.-L. Yang, "Oxidation and absorption of nitric oxide in a packed tower with sodium hypochlorite aqueous solutions," Environmental Progress, vol. 24, no. 3, pp. 279-288, 2005.

[16] H. Chu, S. Y. Li, and T. W. Chien, "The absorption kinetics of no from flue gas in a stirred tank reactor with $\mathrm{KMnO}_{4} / \mathrm{NaOH}$ solutions," Journal of Environmental Science and Health, Part A: Toxic/Hazardous Substances and Environmental Engineering, vol. 33, no. 5, pp. 801-827, 1998.

[17] N. E. Khan and Y. G. Adewuyi, "Absorption and oxidation of nitric oxide (NO) by aqueous solutions of sodium persulfate in a bubble column reactor," Industrial and Engineering Chemistry Research, vol. 49, no. 18, pp. 8749-8760, 2010.

[18] Y. G. Adewuyi and M. A. Khan, "Nitric oxide removal by combined persulfate and ferrous-EDTA reaction systems," Chemical Engineering Journal, vol. 281, pp. 575-587, 2015.

[19] Y. Li, W. Zhong, J. Ju, T. Wang, and F. Liu, "Experiment on simultaneous absorption of $\mathrm{NO}$ and $\mathrm{SO}_{2}$ from sintering flue gas by oxidizing agents of $\mathrm{KMnO}_{4} / \mathrm{NaClO}^{\prime}$, International Journal of Chemical Reactor Engineering, vol. 12, no. 1, pp. 539-547, 2014.

[20] M. K. Mondal and V. R. Chelluboyana, "New experimental results of combined $\mathrm{SO}_{2}$ and $\mathrm{NO}$ removal from simulated gas stream by $\mathrm{NaClO}$ as low-cost absorbent," Chemical Engineering Journal, vol. 217, pp. 48-53, 2013.

[21] Y. Zhao, R. Hao, and M. Qi, "Integrative process of preoxidation and absorption for simultaneous removal of $\mathrm{SO}_{2}, \mathrm{NO}$ and $\mathrm{Hg}^{0}$," Chemical Engineering Journal, vol. 269, pp. 159-167, 2015.

[22] C.-L. Yang, H. Shaw, and H. D. Perlmutter, "Absorption of no promoted by strong oxidizing agents: 1 . Inorganic oxychlorites in nitric acid," Chemical Engineering Communications, vol. 143, pp. 23-38, 1996.

[23] L. Xiao, B. Cheng, J. S. Mo, H. Q. Wang, and Z. B. Wu, "Removal of $\mathrm{NO}$ and $\mathrm{SO}_{2}$ from flue gas by wet scrubbing using aqueous $\mathrm{NaClO}$ solution," Acta Scientiae Circumstantiae, vol. 31, no. 6, pp. 1175-1180, 2011.

[24] J. Fang, Y. Fu, and C. Shang, "The roles of reactive species in micropollutant degradation in the UV/free chlorine system," Environmental Science and Technology, vol. 48, no. 3, pp. 18591868, 2014.

[25] D. Wang, J. R. Bolton, S. A. Andrews, and R. Hofmann, "UV/chlorine control of drinking water taste and odour at pilot and full-scale," Chemosphere, vol. 136, pp. 239-244, 2015.

[26] Q. Wu, Y. Li, W. Wang, T. Wang, and H. Hu, "Removal of C.I. Reactive Red 2 by low pressure UV/chlorine advanced oxidation," Journal of Environmental Sciences, 2015.

[27] J. E. Forsyth, P. Zhou, Q. Mao, S. S. Asato, J. S. Meschke, and M. C. Dodd, "Enhanced inactivation of Bacillus subtilis spores during solar photolysis of free available chlorine," Environmental Science and Technology, vol. 47, no. 22, pp. 12976-12984, 2013. 
[28] G. V. Buxton and M. S. Subhani, "Radiation chemistry and photochemistry of oxychlorine ions. Part 1.-radiolysis of aqueous solutions of hypochlorite and chlorite ions," Journal of the Chemical Society, Faraday Transactions 1: Physical Chemistry in Condensed Phases, vol. 68, pp. 947-957, 1972.

[29] P. Zhou, G. D. Di Giovanni, J. S. Meschke, and M. C. Dodd, "Enhanced inactivation of Cryptosporidium parvum oocysts during solar photolysis of free available chlorine," Environmental Science \& Technology Letters, vol. 1, no. 11, pp. 453-458, 2014.

[30] E. Ghibaudi, J. R. Barker, and S. W. Benson, "Reaction of NO with hypochlorous acid," International Journal of Chemical Kinetics, vol. 11, no. 8, pp. 843-851, 1979.

[31] B.-R. Deshwal and H.-K. Lee, "Mass transfer in the absorption of $\mathrm{SO}_{2}$ and $\mathrm{NO}_{\mathrm{x}}$ using aqueous euchlorine scrubbing solution," Journal of Environmental Sciences, vol. 21, no. 2, pp. 155-161, 2009.

[32] D. Wang, J. R. Bolton, and R. Hofmann, "Medium pressure UV combined with chlorine advanced oxidation for trichloroethylene destruction in a model water," Water Research, vol. 46, no. 15, pp. 4677-4686, 2012.

[33] R.-T. Guo, W.-G. Pan, X.-B. Zhang et al., "The absorption kinetics of NO into weakly acidic NaClO solution," Separation Science and Technology, vol. 48, no. 18, pp. 2871-2875, 2013. 

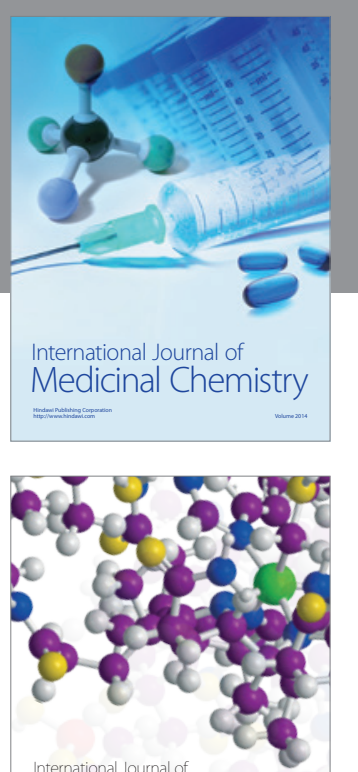

Carbohydrate Chemistry

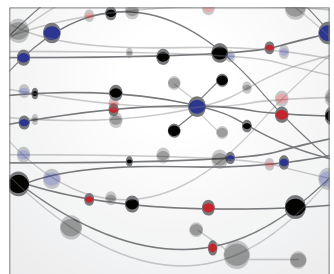

The Scientific World Journal
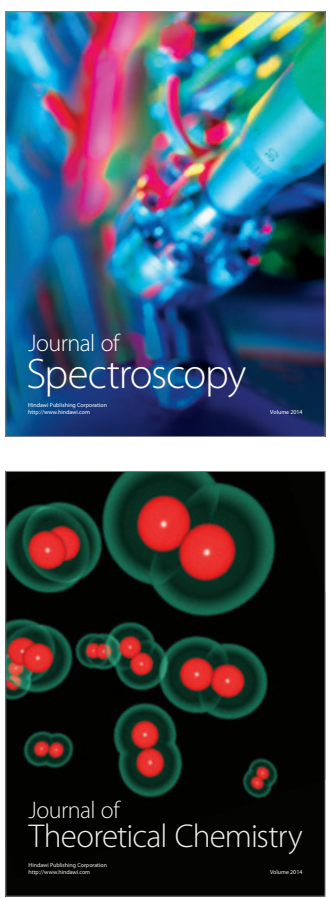
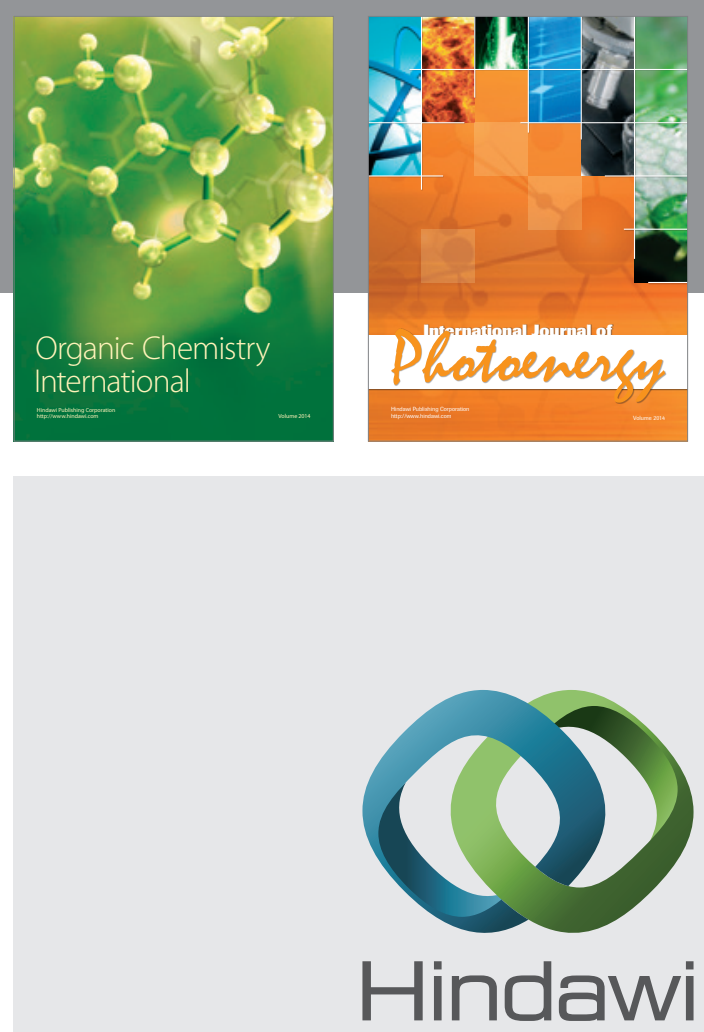

Submit your manuscripts at

http://www.hindawi.com

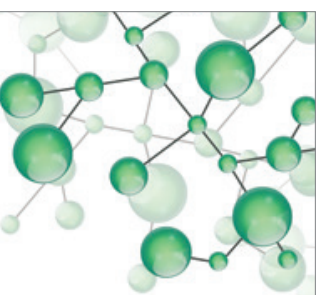

International Journal of

Inorganic Chemistry

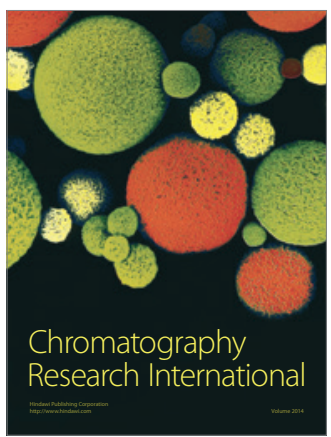

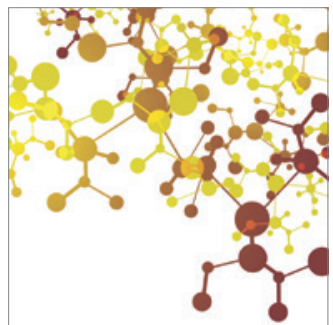

Applied Chemistry
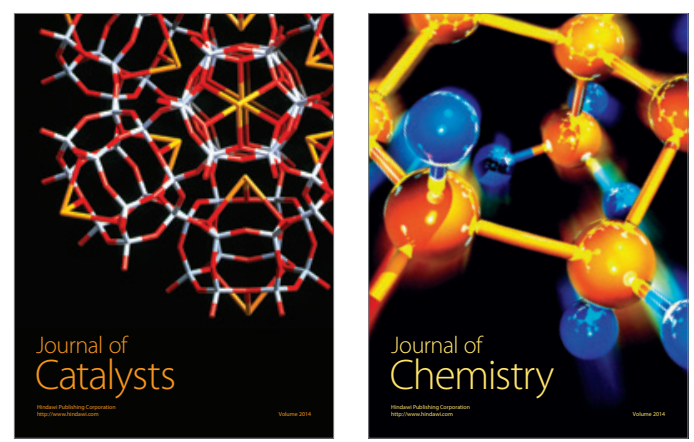
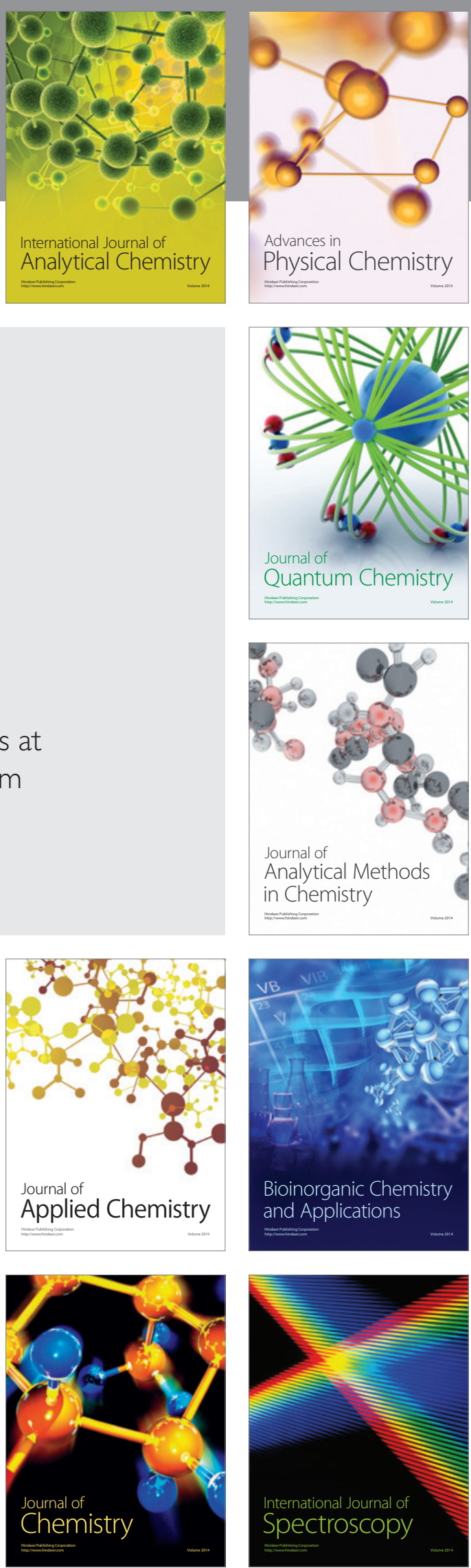